\title{
Arsenic(V) Immobilization in Fly Ash and Lead-Zinc Mine Tailing- based Geopolymer: Performance and Mechanism Insight
}

\section{INTRODUCTION}

Arsenic (As) contamination in water environments (e.g., mine drainage, groundwater, etc.) and soils due to mining activities have raised the risk of arsenic exposure to crop plants (e.g., rice), animals, and humans, and thus aroused growing concern from across the world. $\stackrel{1}{ }$ China holds approximately $70 \%$ of the world's arsenic reservoirs. $\stackrel{2}{2}$ The mining of lead, zinc, and copper ores produced over 32 million tons of arsenic-bearing mine tailing (MT) wastes annually, predominantly in Hunan province, China..$^{-}$In severe situations, these arsenic residues can contaminate the surrounding soils and groundwater, causing serious threats to the sustainability of agroecosystems and food safety. To address this issue, a variety of technologies, including adsorption, bioremediation, chemical-enhanced washing, chemical precipitation, electro-coagulation, electrokinetic method, ionexchange, membrane filtration, phytoremediation, solidification/stabilization (S/S), etc. have been widely exploited and well documented in the literature. $\frac{4-8}{-}$ In terms of soil remediation, adsorption, chemical-enhanced washing, chemical precipitation, and phytoremediation are effective in sequestering and/or immobilizing arsenic, however, both the economic and the environmental restrictions limit their application on a large scale. ${ }^{9}$

Pozzolanic-based solidification/stabilization $(\mathrm{S} / \mathrm{S})$ is a wellestablished, effective, yet cost-efficient remediation technology to immobilize hazardous wastes in contaminated soils and sludges..$\underline{10}$ Arsenic can be effectively immobilized using ordinary Portland cement (OPC) $)^{11-14}$ and magnesium phosphate cement $\frac{15-16}{16}$ as the major cementitious materials. However, the high carbon footprint associated with the production of both types of cement makes the cement-based S/S technology less appealing in the scenario of global carbon neutrality by the middle of the century. $\frac{17}{}$ To this end, low-carbon, high-efficiency S/S technologies using massive industrial by-products, e.g., fly ash, red mud, blast-furnace and/or smelting slag, mine tailing, flue gas desulfurization (FGD) gypsum, etc. as the alternative cementitious materials have received much attention and been extensively studied. $., \underline{2}, \underline{18-20}$

Of various $\mathrm{S} / \mathrm{S}$ technologies, geopolymerization of the mixture of arsenic-bearing waste and the silica- and/or alumina-rich industrial solid wastes (e.g., fly ash, red mud, mine tailing, etc.) by alkali activation has been demonstrated to be an effective alternative to immobilize arsenic into the geopolymer matrix. $\frac{18-19}{}$, 21-23 Geopolymer binders derived from both the alkali activation of coal fly ash $\underline{21}$ and the high-energy ball milling activation of granulated lead smelting slag 22 have shown excellent ability to stabilize the municipal solid waste incinerator fly ash (MSWI FA) with high arsenic content. Recently, it was reported that red mudmetakaolin (MK) based geopolymer shows a good arsenic retention capability as well as a high compressive strength $(\sim 15$ $\mathrm{MPa})$, making it an environmentally friendly backfilling material for sustainable remediation of arsenic pollution. $\stackrel{19}{ }$ However, the production of $\mathrm{MK}$ by calcining kaolinite $\left(\right.$ at $700{ }^{\circ} \mathrm{C}$ ) can yield high $\mathrm{CO}_{2}$ emissions, even though kaolinite clays (> 40\% kaolinite) are inexpensive and widely accessible. ${ }^{24}$ Compared to metakaolinbased geopolymers, mine tailing-based geopolymers have a lower carbon footprint, making them more desirable for use as building materials and as a matrix for immobilizing toxic wastes. $\underline{23}, \underline{25-27}$ For instance, when using sugar mill lime sludge as a Ca-based activator, it was suggested that coal fly ash and mine tailing-based geopolymer can effectively stabilize the mine tailings with high levels of arsenic and heavy metals. Besides, since the geopolymer has high compressive strength (>7.5 MPa), it can also be used as construction materials. $\underline{\underline{23}}$

While many studies have demonstrated that geopolymer matrix plays a crucial role in the immobilization of arsenic wastes, the underlying mechanisms remain poorly understood due to the contradictory results that have often been presented. During the geopolymerization process, arsenic can react either with calciumrich components to form calcium arsenate precipitates, with Friedel's salt to yield As-Friedel's salt mineral, or with the geopolymer gels (e.g., calcium silicate hydrate $(\mathrm{CSH})$, calcium aluminum hydrate (CAH)) to form surface complexes. $\underline{20}, \underline{22}$ Zhou et al. claimed that ion exchange with ettringite, formation of CaAs and Fe-As precipitates, and physical encapsulation with geopolymer gel were the predominant mechanisms for stabilizing arsenic. ${ }^{19}$ However, other studies showed that arsenic exhibits a poor immobilization potential in geopolymer systems due to its high $\mathrm{pH}$ sensitivity. $\frac{28-29}{}$ In this regard, the interactions between 
Table $1 \mid$ Geopolymer specimen composition matrix and characterization tests conducted.

\begin{tabular}{|c|c|c|c|c|c|c|c|c|c|c|c|}
\hline Specimen ID & $\begin{array}{l}\mathrm{NaOH} \\
(\mathrm{M})\end{array}$ & $\begin{array}{c}\text { FA content } \\
\text { (wt. } \%)\end{array}$ & $\begin{array}{c}\text { GY content } \\
\text { (wt.\%) }\end{array}$ & $\begin{array}{c}\mathbf{A s}^{\mathrm{v}} \text { content } \\
\text { (wt. \%) }\end{array}$ & $\mathrm{Si} / \mathbf{A l}^{a}$ & $\mathbf{N a} / \mathbf{A l}^{a}$ & $\begin{array}{c}\text { Curing time } \\
\text { (days) }\end{array}$ & UCS test & XRD & SEM & FTIR \\
\hline FMA5G-02a & 5 & 54 & 2.5 & 0.01 & 0.83 & 0.41 & $7,14,28$ & $\bar{X}$ & & $\bar{X}$ & \\
\hline FMA5G-02b & 5 & 54 & 2.5 & 0.03 & 0.83 & 0.41 & $7,14,28$ & $X$ & $X$ & $X$ & $X$ \\
\hline FMA5G-02c & 5 & 54 & 2.5 & 0.05 & 0.83 & 0.41 & $7,14,28$ & $\mathrm{X}$ & & $\mathrm{X}$ & \\
\hline FMA8G-02a & 8 & 54 & 2.5 & 0.01 & 0.83 & 0.52 & $7,14,28$ & $\mathrm{X}$ & & & \\
\hline FMA8G-02b & 8 & 54 & 2.5 & 0.03 & 0.83 & 0.52 & $7,14,28$ & $X$ & & $X$ & \\
\hline FMA8G-02c & 8 & 54 & 2.5 & 0.05 & 0.83 & 0.52 & $7,14,28$ & $X$ & $X$ & $X$ & $X$ \\
\hline FMA10G-01a & 10 & 61 & 2.5 & 0.01 & 0.94 & 0.46 & $7,14,28$ & $X$ & $\mathrm{X}$ & $X$ & \\
\hline FMA10G-01b & 10 & 61 & 2.5 & 0.03 & 0.94 & 0.46 & $7,14,28$ & $X$ & & & \\
\hline FMA10G-01c & 10 & 61 & 2.5 & 0.05 & 0.94 & 0.46 & $7,14,28$ & $X$ & & $\mathrm{X}$ & \\
\hline FMA10G-02a & 10 & 54 & 2.5 & 0.01 & 0.83 & 0.60 & $7,14,28$ & $X$ & $X$ & $X$ & $X$ \\
\hline FMA10G-02b & 10 & 54 & 2.5 & 0.03 & 0.83 & 0.60 & $7,14,28$ & $\mathrm{X}$ & $\mathrm{X}$ & $\mathrm{X}$ & $\mathrm{X}$ \\
\hline FMA10G-02c & 10 & 54 & 2.5 & 0.05 & 0.83 & 0.60 & $7,14,28$ & $X$ & $X$ & $X$ & $X$ \\
\hline FMA10G-03a & 10 & 44 & 2.5 & 0.01 & 0.68 & 0.87 & $7,14,28$ & $X$ & & $\mathrm{X}$ & \\
\hline FMA10G-03b & 10 & 44 & 2.5 & 0.03 & 0.68 & 0.87 & $7,14,28$ & $\mathrm{X}$ & & & \\
\hline FMA10G-03c & 10 & 44 & 2.5 & 0.05 & 0.68 & 0.87 & $7,14,28$ & $X$ & & $\mathrm{X}$ & \\
\hline FMA10G-04a & 10 & 28 & 2.5 & 0.01 & 0.43 & 1.62 & $7,14,28$ & $\mathrm{X}$ & & $\mathrm{X}$ & \\
\hline FMA10G-04b & 10 & 28 & 2.5 & 0.03 & 0.43 & 1.62 & $7,14,28$ & $X$ & & & \\
\hline FMA10G-04c & 10 & 28 & 2.5 & 0.05 & 0.43 & 1.62 & $7,14,28$ & $X$ & & & \\
\hline FMA5G5-02a & 5 & 54 & 5 & 0.01 & 0.83 & 0.41 & $7,14,28$ & $X$ & & & \\
\hline FMA5G5-02b & 5 & 54 & 5 & 0.03 & 0.83 & 0.41 & $7,14,28$ & $X$ & & & \\
\hline FMA5G5-02c & 5 & 54 & 5 & 0.05 & 0.83 & 0.41 & $7,14,28$ & $X$ & & & \\
\hline FMA8G5-02a & 8 & 54 & 5 & 0.01 & 0.83 & 0.52 & $7,14,28$ & $X$ & $\mathrm{X}$ & $\mathrm{X}$ & $X$ \\
\hline FMA8G5-02b & 8 & 54 & 5 & 0.03 & 0.83 & 0.52 & $7,14,28$ & $\mathrm{X}$ & & $\mathrm{X}$ & \\
\hline FMA8G5-02c & 8 & 54 & 5 & 0.05 & 0.83 & 0.52 & $7,14,28$ & $X$ & & & \\
\hline FMA10G5-02a & 10 & 54 & 5 & 0.01 & 0.83 & 0.60 & $7,14,28$ & $X$ & $X$ & $\mathrm{X}$ & $X$ \\
\hline FMA10G5-02b & 10 & 54 & 5 & 0.03 & 0.83 & 0.60 & $7,14,28$ & $X$ & & & \\
\hline FMA10G5-02c & 10 & 54 & 5 & 0.05 & 0.83 & 0.60 & $7,14,28$ & $X$ & & $\mathrm{X}$ & \\
\hline
\end{tabular}

${ }^{a}$ Note: the calculated $\mathrm{Si} / \mathrm{Al}$ and $\mathrm{Na} / \mathrm{Al}$ ratios in the initial mixtures are not necessarily the same as the final ratios in the geopolymer gels.

arsenic and the mine tailing-based geopolymer matrix and the immobilization mechanism of arsenic should be further elucidated.

In this study, we focus on the feasibility of immobilizing arsenate $\left(\mathrm{As}^{\mathrm{V}}\right)$ in geopolymer matrices derived from the mixtures of fly ash, lead-zinc mine tailing, and FGD gypsum that were activated with sodium hydroxide and sodium silicate solution. The geopolymer specimens were investigated at different $\mathrm{As}^{\mathrm{V}}$ contents, $\mathrm{NaOH}$ concentrations, FA contents, GY contents, curing time, etc. to explore the mechanic properties, microstructure, $\mathrm{As}^{\mathrm{V}}$ leaching characteristics, and the immobilization mechanism of arsenic by using unconfined compressive strength (UCS) test, X-ray diffraction (XRD), scanning electron microscopy (SEM), and Fourier Transform Infrared (FTIR) analyses.

\section{MATERIALS AND METHODS}

Materials. The raw materials used in this study include leadzinc $(\mathrm{Pb}-\mathrm{Zn})$ mine tailings (MT), class F fly ash (FA), and FGD gypsum $(\mathrm{GY})$. Both the FA and the GY were obtained from Jiangsu Nanre Power Generation Co., Ltd. (Nanjing, China). The MT was provided by Nanjing Yinmao Pb-Zn Mining Industry Co., Ltd. (Nanjing, China). The physicochemical characteristics of both the FA and the MT can be found elsewhere. ${ }^{27}$ The GY consists of kidney bean-shaped gypsum $\left(\mathrm{CaSO}_{4} \cdot 2 \mathrm{H}_{2} \mathrm{O}\right.$, JCPDS \#33-0311) powders of size ranging from $\sim 10$ to $\sim 55 \mu \mathrm{m}$ (see Figure $\mathrm{S} 1$ in the Supporting Information).

Reagent grade $96 \% \mathrm{NaOH}$ pellets were purchased from Macklin Biochemical Co., Ltd. (Shanghai, China). Sodium silicate (SS) solution with silica to sodium oxide molar ratio of 2:2 - 2.31 was obtained from Ganjiashan Yourui Refractories Co., Ltd. (Nanjing, China). Sodium arsenate dibasic heptahydrate $\left(\mathrm{Na}_{2} \mathrm{HAsO}_{4} \cdot 7 \mathrm{H}_{2} \mathrm{O}\right.$,
98\%) was purchased from Sigma-Aldrich (Shanghai, China) and used as the arsenate source. All the chemicals were used as received without further purification. Deionized water was used in preparation solutions and the geopolymer.

Preparation and characterization of geopolymer. For the preparation of FA/MT-based geopolymer, FA was fully mixed with MT at a given content, i.e., 28, 44, 54, and $61 \mathrm{wt} . \%$ (by total solid mass) to form a dry-blend. Then the $\mathrm{NaOH}(5,8$, and $10 \mathrm{M})$ together with $25 \mathrm{~g}$ of SS and deionized water were slowly added to the above dry-blend while mixing gently until a homogeneous paste was formed. The liquid to solid (L/S) ratio was kept at $0.3-$ 0.4 to achieve a paste with good workability. The resultant paste was then cast into the six-in-one cubic steel molds $(20 \times 20 \times 20$ $\mathrm{mm}^{3}$ ) at room temperature for $24 \mathrm{~h}$. The shaped cubic geopolymer specimens were demolded carefully and placed in an oven for curing at $65{ }^{\circ} \mathrm{C}$ for another $24 \mathrm{~h}$. After cooling, the specimens were left in the lab tray and cured at room temperature for 7,14 , and 28 days before further tests. All the geopolymer specimens were prepared in triplicate. To study the effect of GY content on the mechanical strength as well as the $\mathrm{As}^{\mathrm{V}}$ immobilization performance of the FA/MT-based geopolymer specimens, 2.5 and 5 wt.\% of GY (by total solid mass) were added into the dry-blend. In the case of preparing geopolymer for $\mathrm{As}^{\mathrm{V}}$ immobilization, 0.01, 0.03 , and 0.05 wt.\% of arsenic were added along with the $\mathrm{NaOH}$ solution. The geopolymer specimen composition matrix is summarized in Table 1.

The unconfined compressive strength (UCS) tests were performed to evaluate the effects of $\mathrm{NaOH}$ concentration, incorporated GY, curing time, and introduction of $\mathrm{As}^{\mathrm{V}}$ on the mechanical strength of the resultant geopolymer specimens. After 7-, 14-, and 28-day curing, the geopolymer specimens were tested 
on a WDW-100 universal material testing machine (Jinan Fangyuan Test Instrument Co., Ltd., China) at a constant loading of $5 \mathrm{MPa} / \mathrm{s}$ in terms of the ASTM C109M-2008 standard. Each geopolymer sample was tested in triplicate and the average UCS value was used for further analysis.

To investigate the microscopic characteristics of geopolymer, the crushed specimens from the UCS tests were collected and further milled into fine powders for further tests. X-ray diffraction (XRD) analysis was conducted on an XRD-6100 diffractometer (Shimadzu, Japan) at a tube voltage of $40 \mathrm{kV}$ and a tube current of $30 \mathrm{~mA}$ with $\mathrm{Cu}-\mathrm{K} \alpha$ radiation (step size: 0.02 , scanning rate: $5 \% \mathrm{~min}$ ). The morphological images of the geopolymer specimens were obtained on a SU1510 (Hitachi, Japan) scanning electron microscope (SEM) at an accelerating voltage of $1.5 \mathrm{kV}$. Fourier Transform Infrared Spectroscopy (FTIR) data were collected on Is5 infrared spectrometer (Thermo Nicolet, USA) by using the $\mathrm{KBr}$ pellet method.

Leaching tests. To evaluate the $\mathrm{As}^{\mathrm{V}}$ immobilization performance of the FA/MT-geopolymers, the Toxicity Characteristic Leaching Procedure (TCLP) procedure tests were conducted following the US EPA test method 1311. $\underline{\underline{30}}$ The leachates were filtered with $0.45 \mu \mathrm{m}$ filters (Tianjin Navigator Lab Instrument Co., Ltd, China) and acidified with ultrapure nitric acid (Sinopharm Chemical, Shanghai, China) before further analyses. $\mathrm{As}^{\mathrm{V}}$ concentrations in the leachates were measured using an Optima 8000 Inductively Coupled Plasma-Optical Emission Spectrometry (ICP-OES) analyzer (PerkinElmer Inc., USA). All the TCLP tests were performed in triplicate and average values were used. The $\mathrm{As}^{\mathrm{V}}$ immobilization efficiency was determined using the following equation,

$$
\text { Immobilization } \%=\frac{C_{0}-C_{\mathrm{f}}}{C_{0}} \times 100 \%
$$

where $\mathbf{C}_{0}$ is the $\mathrm{As}^{\mathrm{V}}$ concentration in the initial suspension of the TCLP test by assuming that all $\mathrm{As}^{\mathrm{V}}$ in the geopolymer specimens are leachable, while $\mathbf{C}_{\mathrm{f}}$ is the measured $\mathrm{As}^{\mathrm{V}}$ concentration in the corresponding leachate $\left(\mathrm{mg} \cdot \mathrm{L}^{-1}\right)$.

\section{RESULTS AND DISCUSSIONS}

Effect of $\mathrm{NaOH}$ concentration on UCS of the FA/MTbased geopolymers. To investigate the effect of $\mathrm{NaOH}$ concentration on the UCS of the FA/MT-based geopolymers, UCS tests were performed on geopolymer specimens with different FA and $\mathrm{As}^{\mathrm{V}}$ contents that were activated with 5,8 , and $10 \mathrm{M} \mathrm{NaOH}$, respectively (Figures 1a, 1b, S2 and S3). As in the case in Figure 1a, apart from geopolymers with 28 wt. $\%$ of FA, the UCS values after curing for 7 days (abbreviated as 7-day UCS) of the FA/MTbased geopolymers increase almost linearly with increasing $\mathrm{NaOH}$ concentrations ranging from 5 to $10 \mathrm{M}$. This near-linear dependency between the UCS and the $\mathrm{NaOH}$ concentration is also evident for these geopolymer specimens cured for 14, and 28 days, respectively (Figures $\mathrm{S} 2$ and $\mathrm{S} 3$ ). It is well established that $\mathrm{NaOH}$ accelerates the dissolution of silicates and aluminosilicates in aqueous systems. $\frac{31}{}$ With increasing $\mathrm{NaOH}$ concentrations, UCS is likely to increase because more $\mathrm{Na}^{+}$and $\mathrm{OH}^{-}$react with the silica- and alumina-rich phase, dissolving more $\mathrm{Si}$ and $\mathrm{Al}$ and thereby increasing the concentration of $\mathrm{Si}$ and $\mathrm{Al}$ in the liquid phase. $\frac{32}{2}$ Faster dissolution of the aluminosilicate phases may lead to faster geopolymer formation due to rapid conversion of the raw materials. Besides, it is believed that during the formation of geopolymer, $\mathrm{Na}^{+}$and $\mathrm{OH}^{-}$ions also play significant roles in stabilizing aqueous species and colloids, increasing the solubility limits of silica and alumina, reducing electrostatic repulsion between the dissolved anions, and catalyzing geopolymer gel formation and rearrangement. $\frac{31}{}$ These will in turn lead to faster geopolymer formation, and thereby increase the geopolymer compressive strength. The UCS improvement with $\mathrm{NaOH}$ concentration has also been observed previously, $\underline{27}, \underline{31-34}$ especially in mixtures with a large number of amorphous aluminosilicate phases. $\underline{32}, \underline{35}$ This observation is also validated in the present study that the activation of the FA/MT mixtures with $10 \mathrm{M} \mathrm{NaOH}$ resulted in the highest UCS (i.e., 35.52 and $37.07 \mathrm{MPa}$ for 7-day and 28-day UCS, respectively) when the mixture with FA content as high as 54 wt. \% was used (Figures 1a and S2b). This is because FA particles contain more amorphous phases than the MT powder and are thereby more reactive to the $\mathrm{NaOH}$ solution. $\underline{27}$

It is of interest to note, however, that the UCS value of geopolymer specimen activated with $10 \mathrm{M} \mathrm{NaOH}$ is lower than that activated with $8 \mathrm{M} \mathrm{NaOH}$ in the case of geopolymers with 28 wt.\% of FA (Figures 1a and S2). This can be explained by the negative effect of excess $\mathrm{NaOH}$ on geopolymer formation which has also been observed previously. $\frac{31}{1} \underline{36}$ Geopolymer compressive strength is believed to increase with increasing $\mathrm{Na} / \mathrm{Al}$ molar ratios up to a specific maximum value, above which the strength is
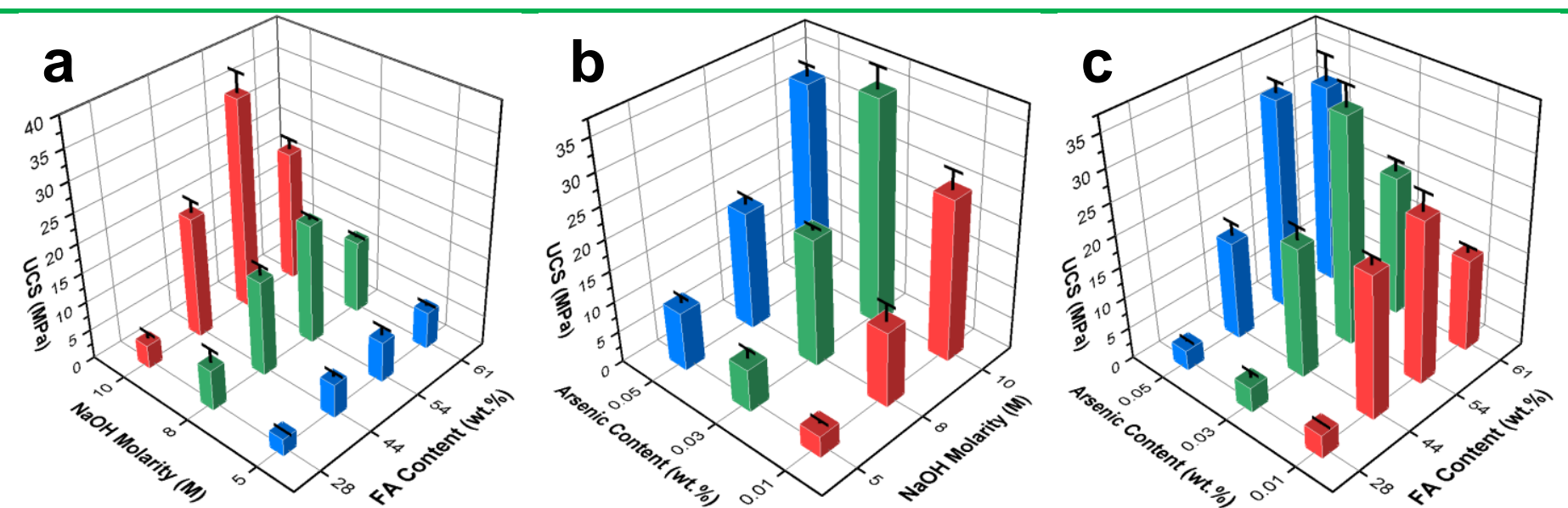

Figure $1 \mid$ (a) Effect of $\mathrm{NaOH}$ concentration and FA content on the 7-day UCS of FT/MT-based geopolymer specimens with a constant As ${ }^{\mathrm{V}}$ content of 0.03 wt.\%, (b) Effect of $\mathrm{NaOH}$ concentration and $\mathrm{As}^{\mathrm{V}}$ content on the 7-day UCS of specimens with a constant FA content of 54 wt.\%, (c) Effect of $\mathrm{As}^{\mathrm{V}}$ and FA contents on the 7-day UCS of specimens activated with $10 \mathrm{M} \mathrm{NaOH}$. 
reduced. $\underline{31}, \underline{36}$ Based on this argument, it would appear that the $\mathrm{Na} / \mathrm{Al}$ molar ratio has reached up to the maximum value favorable for the geopolymer formation in the specimen with $28 \mathrm{wt}$ \% of FA that was activated with $8 \mathrm{M} \mathrm{NaOH}$.

Effect of FA, AsV and GY contents on UCS. As shown in Figures 1a and S2, all the UCS values (i.e., 7-, 14- and 28-day UCS) increase with FA contents ranging from 28 to 54 wt.\%, while decrease to some extent when the FA contents are as high as 61 wt. $\%$ at $\mathrm{NaOH}$ concentrations of 5, 8 and $10 \mathrm{M}$, respectively. As discussed above, it appears that the $\mathrm{Na} / \mathrm{Al}$ molar ratios have achieved the optimum value favoring geopolymer formation when the FA contents increased up to $54 \mathrm{wt} . \%$, indicating that the FA/MT mixture containing $54 \mathrm{wt} . \% \mathrm{FA}$ is the optimal recipe for geopolymer formation regarding the compressive strength. Further increasing the FA proportion in the FA/MT mixtures will no doubt result in decreased $\mathrm{Na} / \mathrm{Al}$ molar ratios, and thus declined compressive strengths. This behavior is in good consistency with the calculated $\mathrm{Na} / \mathrm{Al}$ data (Table 1) and has also been reported elsewhere. $\underline{\underline{37}}$
In general, $\mathrm{Na}^{+}$ions from the alkali activator (e.g., $\mathrm{NaOH}$ ) can reduce the electrostatic repulsion between the dissolved anions through the formation of ion-pairing complexes (e.g., $\mathrm{Si} / \mathrm{Al}-\mathrm{O}^{-} \ldots$ $\mathrm{Na}^{+}$), by which to accelerate the geopolymer gel formation. $\frac{31}{}$ As mentioned above, $0.01-0.05$ wt. $\%$ of $\mathrm{As}^{\mathrm{V}}$ was added to the geopolymer mixtures in the form of sodium arsenate to evaluate the immobilization performance in this study. This suggests that the $\mathrm{Na}^{+}$ions from sodium arsenate will somewhat contribute to the geopolymer gel formation, especially when the $\mathrm{Na}^{+}$ions from $\mathrm{NaOH}$ are very limited. The effect of $\mathrm{As}^{\mathrm{V}}$ content on the UCS is distinct in the cases of geopolymer specimens with $54 \mathrm{wt} . \%$ of FA and $5 \mathrm{M} \mathrm{NaOH}$, which demonstrates that the UCS values increase proportionally as the $\mathrm{As}^{\mathrm{V}}$ contents increase from $0.01 \mathrm{wt} . \%$ to 0.05 wt.\% (Figures $1 \mathrm{~b}$ and $\mathrm{S} 3$ ), confirming the profound contribution from the $\mathrm{Na}^{+}$ions of sodium arsenate. Similar observations are also notable in geopolymer specimens with $61 \mathrm{wt} . \% \mathrm{FA}$ and $10 \mathrm{M}$ $\mathrm{NaOH}$ as shown in Figures $1 \mathrm{c}$ and $\mathrm{S} 4$, where $\mathrm{Na}^{+}$ions from $\mathrm{NaOH}$ are inadequate to dissolve the amorphous phases in FA of the mixtures, and therefore the introduction of extra $\mathrm{Na}^{+}$ions along
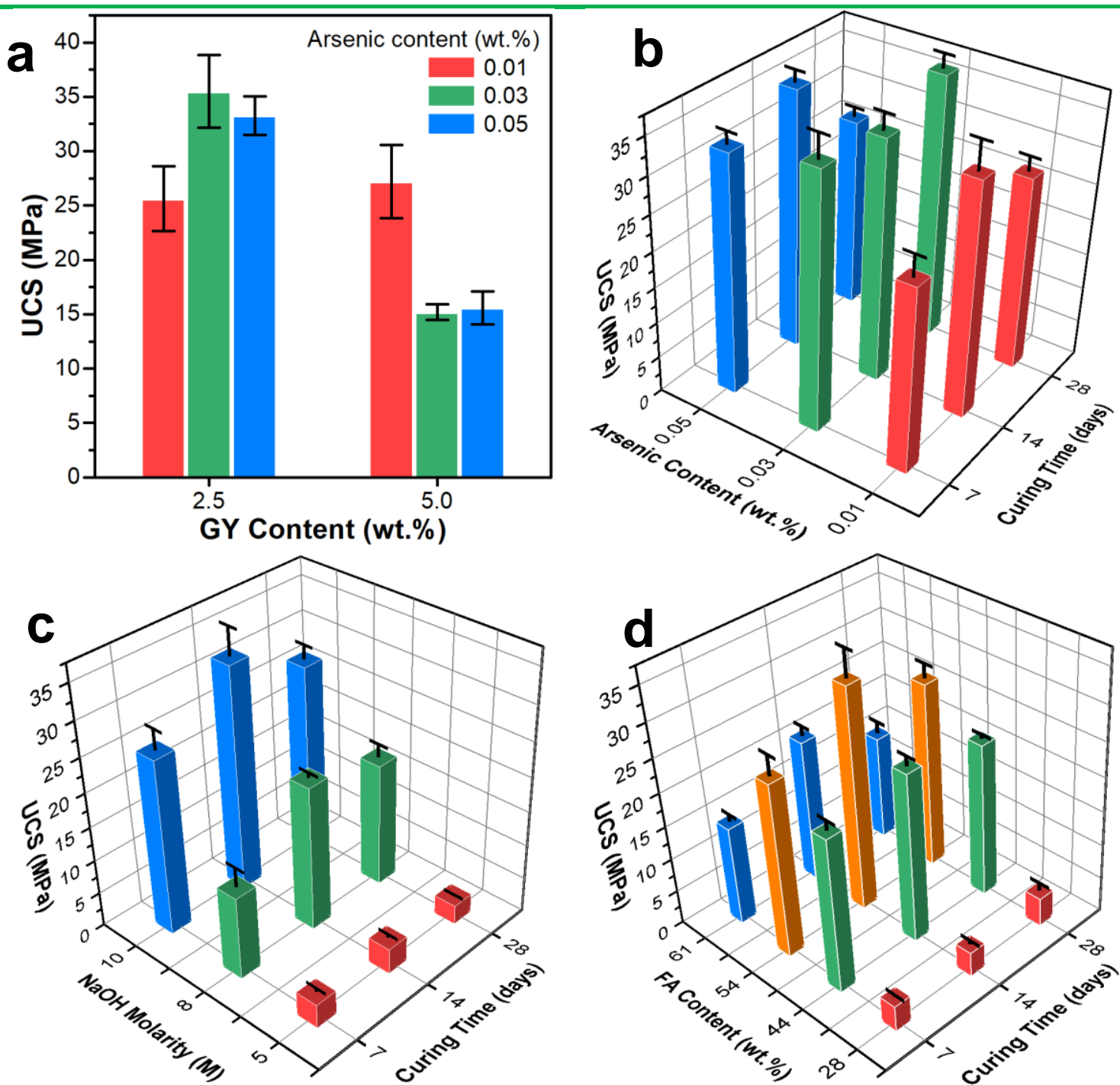

Figure 2 | (a) Effect of GY content on the 7-day UCS of specimens (54 wt.\% FA, $10 \mathrm{M} \mathrm{NaOH})$; (b) Effect of curing time and As ${ }^{\mathrm{V}}$ content on the UCS of the same specimens; (c) Effect of curing time and $\mathrm{NaOH}$ concentration on the UCS of specimens (54 wt.\% FA, and 0.01 wt.\% $\left.\mathrm{As}^{\mathrm{V}}\right)$; and (d) Effect of curing time and FA content on the UCS of specimens ( $0.01 \mathrm{wt} . \% \mathrm{As}^{\mathrm{V}}$, and $\left.10 \mathrm{M} \mathrm{NaOH}\right)$. 
with $\mathrm{As}^{\mathrm{V}}$ sources can result in obvious increases in the compressive strengths. In other geopolymer specimens rich in $\mathrm{Na}^{+}$ ions from $\mathrm{NaOH}$ (with high $\mathrm{Na} / \mathrm{Al}$ molar ratios) as shown in Figures $1 \mathrm{~b}, 1 \mathrm{c}, \mathrm{S} 3$, and $\mathrm{S} 4$, the effect of $\mathrm{As}^{\mathrm{V}}$ content appears to be stochastic since excess $\mathrm{Na}^{+}$ions in the geopolymer system can reduce the compressive strength. $\underline{\underline{31}}, \underline{36}$

Gypsum is known to accelerate the induration and the early strength of the geopolymer, promoting arsenic solidification to some extent. $2, \underline{10}, \underline{38-39}$ Nevertheless, excess gypsum in geopolymer mixture appears to increase the mobility of arsenic, $, 2, \underline{20}$ and reduce the compressive strength of the resultant geopolymer. For the leachability of toxics and the compressive strength, the addition of $8-12$ wt.\% of gypsum to the geopolymer mixture is well established in the literature. ${ }^{2}, \underline{39}$ However, our results in Figure $2 \mathrm{a}$ demonstrate that introduction of $5 \mathrm{wt}$.\% of FGD gypsum can lead to significant decreases in the UCS values of geopolymers $(\mathrm{NaOH}$ $=10 \mathrm{M}$, FA content $=54 \mathrm{wt} . \%$ ), as compared to those with $2.5 \mathrm{wt} . \%$ gypsums. Therefore, we mainly focus on the geopolymer mixtures with a GY content of 2.5 wt.\% in the present study, and all geopolymer mixtures were blended with 2.5 wt.\% of GY unless otherwise specified. Moreover, it is worthy to note that the highest UCS of $39.46 \mathrm{MPa}$ can be found in geopolymer specimens with 61 wt.\% FA, 0.05 wt.\% $\mathrm{As}^{\mathrm{V}}$ and $10 \mathrm{M} \mathrm{NaOH}$ after curing for 14 days (see the supplementary UCS data). Besides, this geopolymer has a 28-day UCS as high as $31.88 \mathrm{MPa}$. In comparison to conventional FA-based geopolymers, $, \underline{18}, \underline{20}, \underline{22}, \underline{32}$ the geopolymer exhibits superior compressive strength, making it an attractive material for use in construction.

Effect of curing time on UCS. It has been reported previously that for FA-based geopolymer systems the temperature at which specimens are cured significantly affects its final compressive strength. $\underline{41}$ Our previous work has also confirmed that curing at $65{ }^{\circ} \mathrm{C}$ can improve the overall strength of the geopolymer specimens as compared to those cured at $25^{\circ} \mathrm{C}$. 27 Therefore, the effect of curing time on UCS in this study was investigated by evaluating the compressive strength of specimens cured at $65{ }^{\circ} \mathrm{C}$ for different curing times. Geopolymer specimens prepared with varying $\mathrm{FA}$ and $\mathrm{As} \mathrm{v}^{\mathrm{V}}$ contents, $\mathrm{NaOH}$ concentrations, and cured for 7,14 , and 28 days were evaluated and the results are presented in Figure $2 b-d$. For all specimens, it appears that the strength of the geopolymers developed rapidly in the first 7 days, accounting for $>70 \%$ of the maximum UCS values that were obtained in 14 days. This observation is in good agreement with previous reports. $\underline{27}, \underline{42-43}$

However, it is of interest to note that the 28-day UCS values decreased slightly (i.e., $9.2-16.6 \%$ ) as compared to the 14-day UCS for most specimens studied (Figure $2 b-d$ ). This may attribute to the structural weakening of geopolymer gels due to the loss of structural water during the curing at elevated temperature (i.e., $65^{\circ} \mathrm{C}$ ), ${ }^{41}$ and the reduction in compactness owing to the phase transitions from amorphous gels to crystalline minerals. $\underline{16}, \underline{18}$ Nevertheless, it is apparent that when the specimen was prepared with 54 wt.\% FA and $10 \mathrm{M} \mathrm{NaOH}$, curing at $65^{\circ} \mathrm{C}$ for 24 hours can endow the specimen with a 7-day UCS as high as $35.52 \mathrm{MPa}$ (Figure 2b), implying that curing at elevated temperature can not only enhance the early strength of the specimen but also shorten the curing time. $\underline{44}$

Leaching results of $\mathbf{A s} \mathbf{s}^{\mathbf{v}}$. For geopolymer formation, a compacted and consolidated material with relatively high strength is usually preferable, while low permeability is desirable from a leaching point of view when using such geopolymer for the solidification/stabilization of toxic wastes. The TCLP leaching results of $\mathrm{As}^{\mathrm{V}}$ from the geopolymer specimens with different compositions and curing times are given in Table 2 and depicted in Figure 3. The results are quite variable, with leached $\mathrm{As}^{\mathrm{V}}$ concentrations in the leachates (i.e., the $\mathrm{As}^{\mathrm{V}}$ leachabilities) ranging from 0 (not detected, n.d.) to $2.6 \mathrm{mg} / \mathrm{L}$ (Table 2). In the case of geopolymer specimens with $54 \mathrm{wt} \%$ of FA and $10 \mathrm{M}$ of $\mathrm{NaOH}$, curing in the air for 7 days endowed the specimen of $0.03 \mathrm{wt} . \%$ $\mathrm{As}^{\mathrm{V}}$ with the maximum strength (i.e., 35.52 MPa), while presented the highest $\mathrm{As}^{\mathrm{V}}$ leachability (i.e., $2.16 \mathrm{mg} / \mathrm{L}$ ) to the specimen with 0.05 wt. $\% \mathrm{As}^{\mathrm{V}}$ (Figure $3 \mathrm{a}$ ). However, when prolonging the curing time to 14 days, it is of interest to note that both the UCS values and the $\mathrm{As}^{\mathrm{V}}$ leachabilities increase proportionally with the $\mathrm{As}^{\mathrm{V}}$ contents from 0.01 to 0.05 wt. $\%$, which has also been observed previously..$\underline{45}$ Further extending the curing time to 28 days resulted in the maximum strength of the specimen with 0.03 wt.\% $\mathrm{As}^{\mathrm{V}}$ (i.e., 37.07 MPa), while the highest $\mathrm{As}^{\mathrm{V}}$ leachability of that incorporating $0.05 \mathrm{wt} . \%$ of $\mathrm{As}^{\mathrm{V}}$ (i.e., $1.4 \mathrm{mg} / \mathrm{L}$ ). This observation indicates that it is difficult to correlate the $\mathrm{As}^{\mathrm{V}}$ leachability, i.e., the immobilization performance for $\mathrm{As}^{\mathrm{V}}$, with the $\mathrm{As}^{\mathrm{V}}$ content, the UCS, and the curing time. Besides immobilization by geopolymerization, $\mathrm{As}^{\mathrm{V}}$ is also possible fixed by precipitate formation such as calcium arsenate hydrates. $\underline{12}, \underline{20}$

Table $2 \mid \mathrm{As}^{\mathrm{V}}$ leaching test results of geopolymer specimens with different curing time.

\begin{tabular}{|c|c|c|c|c|c|c|c|c|c|c|c|}
\hline \multirow[b]{2}{*}{ Specimen ID } & \multicolumn{3}{|c|}{$\mathrm{As}^{\mathrm{V}}$ leachability (mg/L) } & \multirow[b]{2}{*}{$\begin{array}{c}\text { Specimen } \\
\text { ID }\end{array}$} & \multicolumn{3}{|c|}{$A s^{V}$ leachability (mg/L) } & \multirow[b]{2}{*}{$\begin{array}{c}\text { Specimen } \\
\text { ID }\end{array}$} & \multicolumn{3}{|c|}{$\mathrm{As}^{\mathrm{V}}$ leachability (mg/L) } \\
\hline & $\begin{array}{c}7 \\
\text { days }\end{array}$ & $\begin{array}{c}14 \\
\text { days }\end{array}$ & $\begin{array}{c}28 \\
\text { days }\end{array}$ & & $\begin{array}{c}7 \\
\text { days }\end{array}$ & $\begin{array}{c}14 \\
\text { days }\end{array}$ & $\begin{array}{c}28 \\
\text { days }\end{array}$ & & $\begin{array}{c}7 \\
\text { days }\end{array}$ & $\begin{array}{c}14 \\
\text { days }\end{array}$ & $\begin{array}{c}28 \\
\text { days }\end{array}$ \\
\hline FMA5G-02a & 0.27 & 0.75 & n.d. & FMA10G-02a & 0.31 & 0.02 & 0.01 & FMA5G5-02a & 0.48 & 0.18 & n.a. \\
\hline FMA5G-02b & 2.17 & 1.11 & 0.84 & FMA10G-02b & 1.33 & 0.61 & 0.01 & FMA5G5-02b & 0.94 & 1.42 & 1.00 \\
\hline FMA5G-02c & 2.17 & 1.96 & 2.09 & FMA10G-02c & 2.16 & 1.87 & 1.37 & FMA5G5-02c & n.d. & 2.56 & 0.87 \\
\hline FMA8G-02a & 0.34 & 1.32 & n.d. & FMA10G-03a & 0.12 & n.d. & 0.65 & FMA8G5-02a & 0.83 & n.d. & n.d. \\
\hline FMA8G-02b & 0.58 & 0.72 & 0.22 & FMA10G-03b & n. d. & 0.95 & 0.09 & FMA8G5-02b & 1.05 & 1.33 & n.d. \\
\hline FMA8G-02c & 0.82 & n. d. & 0.83 & FMA10G-03c & 2.53 & 1.87 & 0.78 & FMA8G5-02c & 2.60 & n.d. & 1.77 \\
\hline FMA10G-01a & 0.08 & 0.44 & 0.06 & FMA10G-04a & 0.70 & n. d. & 0.41 & FMA10G5-02a & 0.08 & 1.05 & n.a. \\
\hline FMA10G-01b & 0.57 & 0.63 & 0.31 & FMA10G-04b & n. d. & 0.59 & 0.07 & FMA10G5-02b & 1.05 & 0.81 & 0.13 \\
\hline FMA10G-01c & 0.89 & 1.20 & n.a. & FMA10G-04c & 0.94 & 1.19 & 0.20 & FMA10G5-02c & 1.16 & 0.99 & 1.44 \\
\hline $\begin{array}{l}\text { Chinese } \\
\text { standard }\end{array}$ & 5.0 & 5.0 & 5.0 & & & & & & & & \\
\hline
\end{tabular}



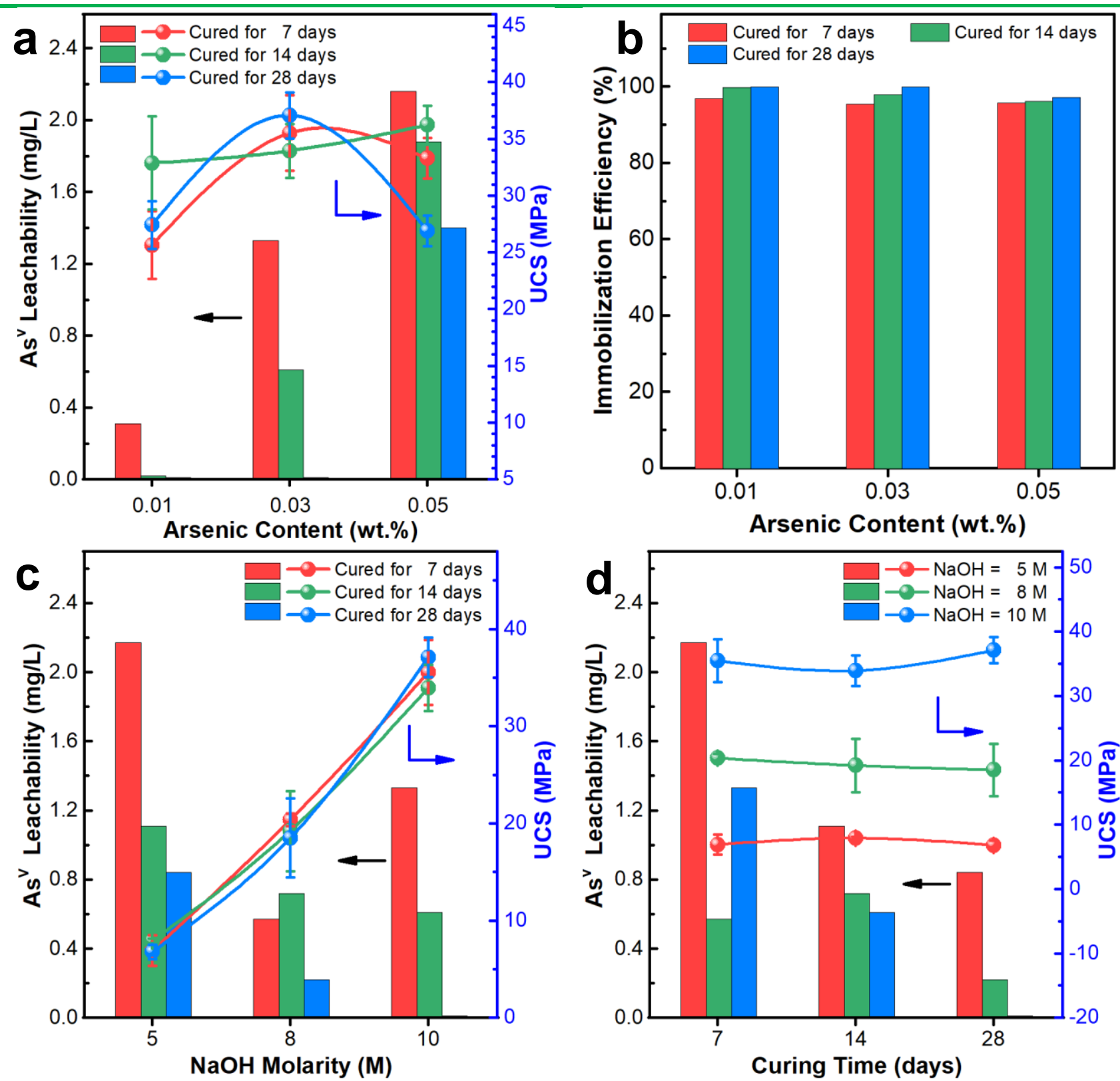

Figure $3 \mid$ Effect of $\mathrm{As}^{\mathrm{V}}$ content on (a) the $\mathrm{As}^{\mathrm{V}}$ leachability and the 7-day UCS, and (b) the As ${ }^{\mathrm{V}}$ immobilization efficiency of geopolymer specimens ( 54 wt.\% FA, $10 \mathrm{M} \mathrm{NaOH}$ ), (c) Effect of $\mathrm{NaOH}$ concentration on the As ${ }^{\mathrm{V}}$ leachability and the UCS of specimens cured for 7 , 14 , and 28 days ( 54 wt.\% FA, and 0.03 wt. $\% \mathrm{As}^{\mathrm{V}}$ ), (d) Effect of curing time on the As ${ }^{\mathrm{V}}$ leachability and the UCS of specimens with 5 , 8 , and $10 \mathrm{M} \mathrm{NaOH}\left(54\right.$ wt. $\%$ FA, and 0.03 wt. $\left.\% \mathrm{As}^{\mathrm{V}}\right)$.

Results in Figure $3 \mathrm{c}$ indicate that the $\mathrm{As}^{\mathrm{V}}$ leachability decreases with increasing $\mathrm{NaOH}$ concentrations from 5 to $10 \mathrm{M}$ for specimens with $54 \mathrm{wt} . \%$ of FA, $0.03 \mathrm{wt} . \% \mathrm{As}^{\mathrm{V}}$ and cured for 14 , and 28 days, respectively, whereas the UCS values increase proportionally with the $\mathrm{NaOH}$ concentrations as discussed above. This can be explained by the fact that higher $\mathrm{NaOH}$ concentration can lead to the faster dissolution of the aluminosilicate phases, and thereby faster geopolymer formation, $\underline{31-32}$ by which free $\mathrm{As}^{\mathrm{V}}$ were consolidated and in turn stabilized.22-23 Furthermore, it is evident that extending the curing time from 7 to 28 days does not improve the compressive strength of these specimens too much (Figure $3 \mathrm{~d}$ ) since specimens are likely to reach their ultimate compressive strength in 7 days for FA/MT-based geopolymer. $\underline{42}$ However, prolonging the curing time can significantly reduce the $\mathrm{As} \mathrm{V}$ leachabilities. For instance, in specimen with $54 \mathrm{wt} . \%$ of FA, 0.03 wt. $\%$ of $\mathrm{As}^{\mathrm{V}}$ and activated with $10 \mathrm{M} \mathrm{NaOH}$ (i.e., FMA10G-02b), a reduction of $\mathrm{As}^{\mathrm{V}}$ leachability from $1.33 \mathrm{mg} / \mathrm{L}$ to $0.01 \mathrm{mg} / \mathrm{L}$ was observed when extending the curing time from 7 to 28 days (Table 2). This is in good agreement with the previous report, $\frac{46}{6}$ confirming that increased curing time appears to reduce the water permeability and porosity of the geopolymer, and thereby enhance the $\mathrm{As}^{\mathrm{V}} \mathrm{S} / \mathrm{S}$ performance as expected.

Besides, the $\mathrm{As}^{\mathrm{V}}$ immobilization efficiencies of all geopolymer specimens are above $95.4 \%$ (Figure $3 \mathrm{~b}$ ), and $\mathrm{As}^{\mathrm{V}}$ leachabilities of all specimens are below $5.0 \mathrm{mg} / \mathrm{L}$ as specified in the standard (Table 2). Moreover, the leachabilities of other heavy metal ions 
including copper $(\mathrm{Cu})$, cadmium $(\mathrm{Cd})$, lead $(\mathrm{Pb})$, and chromium $(\mathrm{Cr})$ are also below the maximum toxic levels (Table $\mathrm{S} 1$ ), indicating that all specimens comply with the Chinese leaching standard for hazardous wastes (GB 5085.3 - 2007). $\stackrel{47}{\text { Therefore, }}$ the FA/MT-based geopolymers demonstrated superior immobilization performance for both $\mathrm{As}^{\mathrm{V}}$ and typical heavy metals and high compressive strengths, especially in specimens with 54 wt. $\%$ of FA activated with $10 \mathrm{M} \mathrm{NaOH}$ (i.e., the FMA10G-02 series). Given the performance of mechanical strengths and contaminant immobilization, FA/MT-based geopolymers can be used for the synchronous $\mathrm{S} / \mathrm{S}$ of $\mathrm{As}^{\mathrm{V}}$ and heavy metalcontaminated soil and sediments.
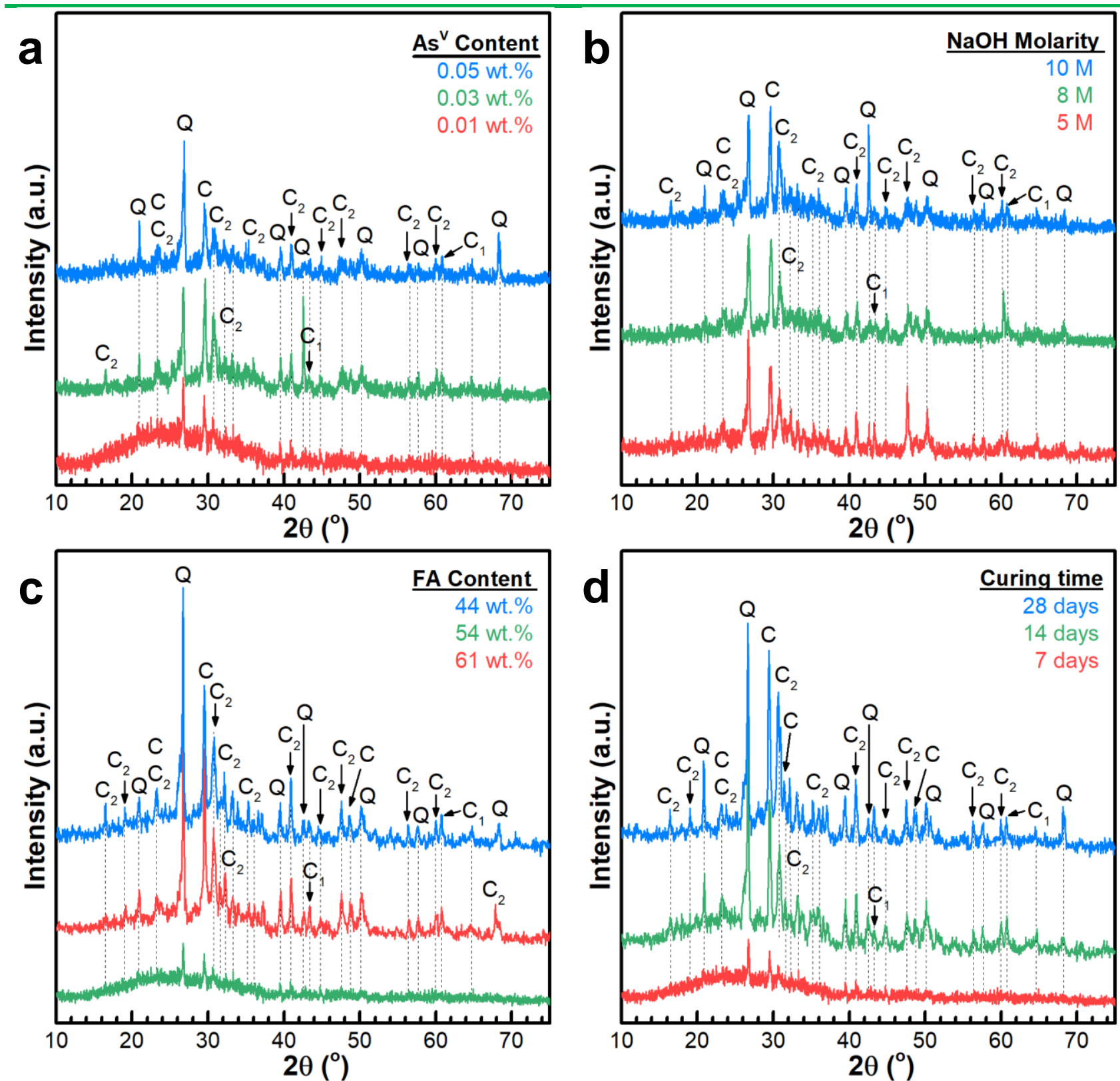

Figure 4 XRD patterns of (a) geopolymer specimens of 54 wt. $\%$ FA, $10 \mathrm{M} \mathrm{NaOH}$ and cured for 7 days with varying arsenic contents; (b) specimens of 54 wt.\% FA, 0.03 wt.\% As ${ }^{\mathrm{V}}$, cured for 7 days and activated with 5, 8, and $10 \mathrm{M} \mathrm{NaOH}$; (c) specimens of 0.01 wt.\% $\mathrm{As}^{\mathrm{v}}, 10 \mathrm{M} \mathrm{NaOH}$ and cured for 7 days with varying FA contents; (d) specimens of 54 wt.\% FA, 0.01 wt.\% As ${ }^{\mathrm{V}}, 10 \mathrm{M} \mathrm{NaOH}$, and cured for different days. $\left(\mathbf{C}: \mathrm{Ca}_{2} \mathrm{SiO}_{4} ; \mathbf{C}_{1}: \mathrm{CaCO}_{3} ; \mathbf{C}_{2}: \mathrm{Ca}_{5}\left(\mathrm{SiO}_{4}\right)_{2}(\mathrm{OH})_{2} ; \mathbf{Q}\right.$ : quartz)

Immobilization mechanism of $\mathbf{A s} \mathbf{v}$. To better understand the underlying mechanism responsible for $\mathrm{As}^{\mathrm{V}}$ immobilization, several geopolymer specimens were collected and ground into fine powders for microstructural characterization (e.g., XRD, SEM, and FTIR). XRD patterns of geopolymer specimens show evidence for calcium silicate ( $\mathrm{Ca}_{2} \mathrm{SiO}_{4}$, JCPDS \#31-0302), calcite
$\left(\mathrm{CaCO}_{3}, \mathrm{JCPDS} \# 05-0586\right)$, calcium silicate hydroxide (CSH, $\mathrm{Ca} 5\left(\mathrm{SiO}_{4}\right)_{2}(\mathrm{OH})_{2}$, JCPDS \#29-0380), quartz ( $\mathrm{SiO}_{2}$, JCPDS \#461045), and amorphous phases (Figures 4, S5-7), all of which were commonly observed in fly ash-based geopolymers. $.31-32, \underline{34}, 41$ Of all specimens containing $\mathrm{As}^{\mathrm{V}}$, no evidence for crystalline calcium arsenate was identified, suggesting that precipitation with calcium 
ions seems not to be the major mechanism for $\mathrm{As}^{\mathrm{V}}$ immobilization in these geopolymer specimens. This is, however, contrary to preceding studies of stabilizing arsenic wastes at high levels with calcium-rich cementitious materials $\underline{9}, \underline{12}, \underline{20}, \underline{38}$ and is likely due to the low $\mathrm{As}^{\mathrm{V}}$ loadings (i.e., $0.01-0.05$ wt.\%) in this study.

Furthermore, it is worthy to note that increasing the $\mathrm{As} v$ contents appears to enhance the phase transition from amorphous to crystalline (Figures 4a and S5), with the highest crystallinity of the specimen containing the maximum $\mathrm{As}^{\mathrm{V}}$ content (i.e., 0.05 wt.\%). This has also been observed in previous reports 9,18 and is likely owing to the hydration inhibition of geopolymer gel by arsenate. The $\mathrm{NaOH}$ concentration is also observed to have a profound effect on the phase composition of the geopolymer, and Figures $4 \mathrm{~b}$ and S6 illustrate the relationship between the $\mathrm{NaOH}$ concentration and the crystalline phase composition. There is an increase in the intensity of reflections at $2 \theta \sim 26.8^{\circ}$ and $29.3^{\circ}$ (attributed to calcium silicate and $\mathrm{CSH}$, respectively) with increasing $\mathrm{NaOH}$ concentration, indicating that higher $\mathrm{NaOH}$ concentration accelerates the much more and faster formation of both calcium silicate and $\mathrm{CSH}$, which is good agreement with the above discussion. Besides, $\mathrm{CSH}$ is believed to act as an effective encapsulator and physical barrier to prevent the leaching of toxic elements from the geopolymer. $\underline{23}, \underline{48}$ This might explain why the specimens activated with $10 \mathrm{M} \mathrm{NaOH}$ demonstrated the best $\mathrm{S} / \mathrm{S}$ performance towards $\mathrm{As}^{\mathrm{V}}$ (Figure 3 and Table 2). Of these specimens activated with $10 \mathrm{M} \mathrm{NaOH}$, those with 54 wt.\% FA and $0.01 \mathrm{wt}^{\circ} \% \mathrm{As}^{\mathrm{V}}$ demonstrated a greater amount of amorphous geopolymer gels as compared to other specimens with different FA and $\mathrm{As}^{\mathrm{V}}$ contents (Figures $4 \mathrm{a}, 4 \mathrm{c}$ ). Since the amorphous gel is likely to form a more compact geopolymer network than the specimens dominated by crystalline phases, $\underline{16}, \underline{18}$ and thereby leading to the maximum UCS (Figure 2d) and the best S/S performance. As discussed earlier and expected, prolonging the curing time will eventually improve the development of crystalline phases (Figures 4d, S7), resulting in loss of the compactness, and thus a slight decrease in the 28-day UCS values (Figure $2 \mathrm{~d}$ and the supplementary UCS data). It is of interest to note, however, that the specimens with 54 wt.\% and $10 \mathrm{M} \mathrm{NaOH}$ (i.e., the FMA10G02 series) showed improved S/S performance towards $\mathrm{As}^{\mathrm{V}}$ with increasing curing time (Figure $3 \mathrm{c}-\mathrm{d}$, Table 2), regardless of the slight reduction in the 28-day UCS values (Figure 2d). This observation reflects that $\mathrm{As}^{\mathrm{V}}$ appears to be incorporated into the crystalline minerals (e.g., calcium silicate and $\mathrm{CSH}$ ) during the phase transition processes as a result of prolonging the curing time. $\underline{3}, \underline{19}$

SEM images of geopolymer specimens with 54 wt.\% FA are shown in Figures 5, 6, and S8. Obviously, three distinct particulates, i.e., the partially and unreacted FA particles, the unreacted MT, and the resultant geopolymer gels, can be identified. The unreacted FA particles are attached or surrounded by the gels which also consolidate and embed some partially reacted FA particles (Figures 5, 6, and S8). No kidney bean-shaped particles corresponding to GY can be found even in specimens with a GY content of 5 wt.\% (Figure S8), implying high reactivity of GY
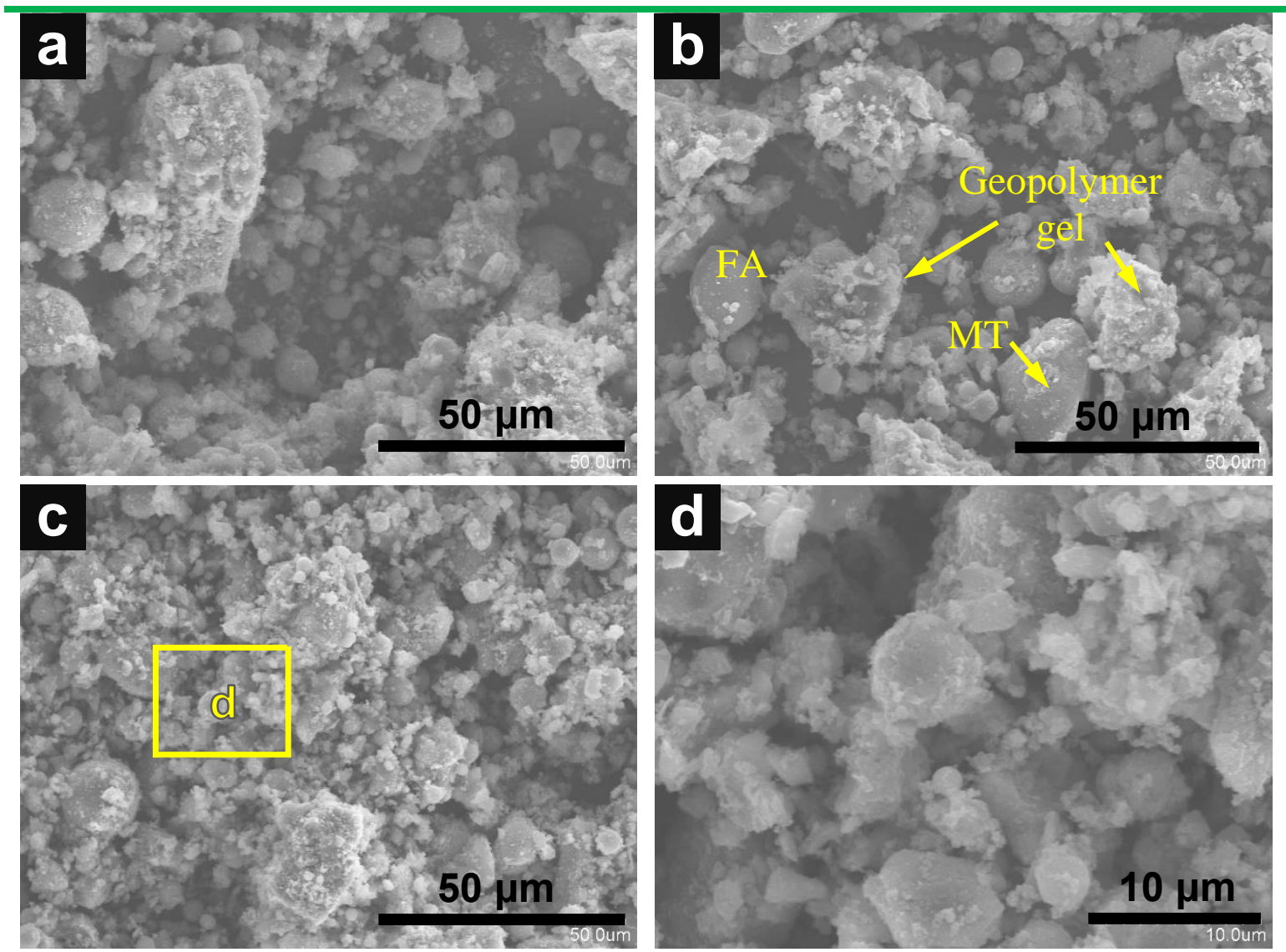

Figure 5 | SEM images of geopolymer specimens of 54 wt.\% FA, cured for 7 days and activated with (a) $5 \mathrm{M} \mathrm{NaOH}$, (b) $8 \mathrm{M} \mathrm{NaOH}$, and $(\mathbf{c}, \mathbf{d}) 10 \mathrm{M} \mathrm{NaOH}$. 

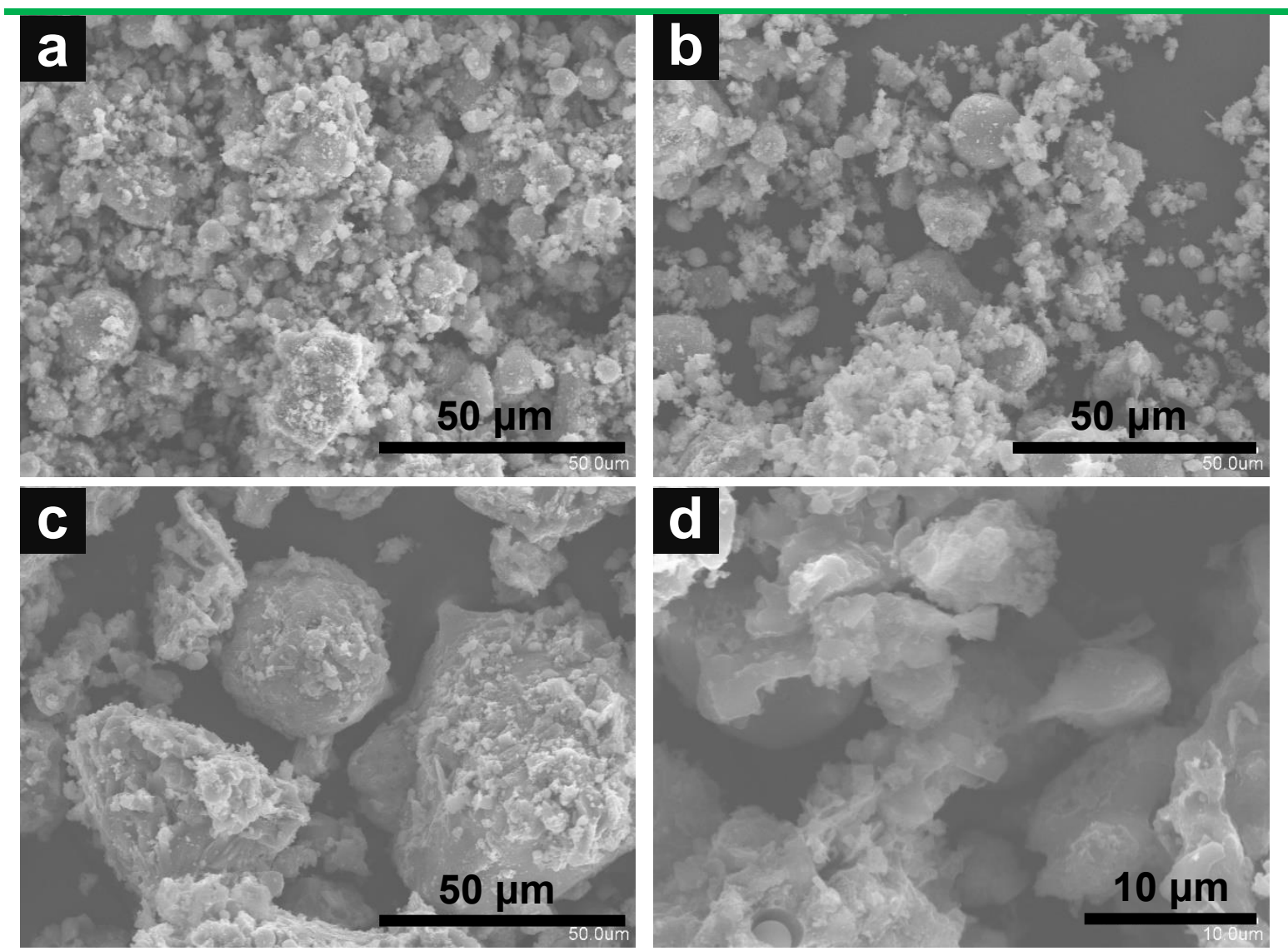

Figure 6 | SEM images of geopolymer specimens of 54 wt.\% FA activated with $10 \mathrm{M} \mathrm{NaOH}$ and cured for (a) 7 days, (b) 14 days, and (c, d) 28 days.

particles in the geopolymerization reaction. Comparison of the micrographs in Figure 5 indicates that as the $\mathrm{NaOH}$ concentration increased from 5 to $10 \mathrm{M}$, the number of unreacted FA particles decreased apparently and the specimens became more compact, implying a higher degree of geopolymerization at higher $\mathrm{NaOH}$

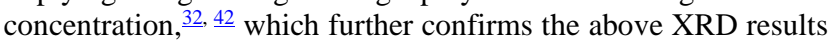
in Figure 4. This observation provides direct microscopical evidence of the superior performance of specimens with 54 wt.\% FA and $10 \mathrm{M} \mathrm{NaOH}$ in both the compressive strength and the $\mathrm{As} \mathrm{V}$ immobilization (Figures 2, 3, and Table 2). Moreover, note that there is no significant change in the microstructure of the specimens with 54 wt. $\%$ and $10 \mathrm{M} \mathrm{NaOH}$ after curing for 7 days ( $c f$. Figure $6 \mathrm{~b} \& \mathrm{c}$ ), confirming the UCS results that a large portion of the UCS was obtained within 7 days (Figure 2d). .42

The FTIR spectra of geopolymer specimens with 54 wt.\% FA are shown in Figure 7. The assignment of characteristic IR bands based on previous studies is summarized in Table 3. Apparently, neither vibrational band attributed to the symmetric stretching of As-O bond for the adsorbed $\mathrm{As}{ }^{\mathrm{V}}$ (i.e., $\sim 830 \mathrm{~cm}^{-1}$ ), nor bands associated with calcium arsenate (i.e., $\sim 860 \mathrm{~cm}^{-1}$ ) are identifiable in both IR spectra, suggesting that neither adsorption nor coprecipitation with calcium ions is likely to contribute to $\mathrm{As}^{\mathrm{V}}$ immobilization. $\underline{12}$ This is in good consistency with the above XRD results (Figure 4). In general, the major Si-O-Si vibration band of the raw FA will undergo broadening and shifting toward a lower the curing time. $\underline{3}, \underline{19}$ wavenumber after geopolymerization owing to the transition of ordered Si-O-Si structure to a less ordered structure with randomly distributed Si-O-Al bonds. $\stackrel{32}{\text {, }} \underline{\text { }}$ Comparison of the geopolymer IR spectra with that of FA reflects a clear shift of band at $1069 \mathrm{~cm}^{-1}$ (assignable to $\mathrm{Si}-\mathrm{O}-\mathrm{Si} / \mathrm{Al}$ vibration) to a lower wavenumber at $1002 \mathrm{~cm}^{-1}$, confirming the formation of geopolymer gels with a less ordered network as evidenced by the XRD data (Figure 4). Besides, the intensity of the $\mathrm{Si}-\mathrm{O}-\mathrm{Si} / \mathrm{Al}$ vibration bands near 1000 $\mathrm{cm}^{-1}$ decreased clearly with increasing $\mathrm{As}^{\mathrm{V}}$ contents, indicating the reduction of the geopolymer gel amount as the $\mathrm{As}^{\mathrm{V}}$ content increased. This is in good agreement with the above XRD results in Figure 4a. It is worthy to note that the bands of asymmetric stretching vibration $\left(\mathrm{v}_{3},-\mathrm{CO}_{3}\right)$ in surface $\mathrm{CaCO}_{3}$ at 1438 and 1485 $\mathrm{cm}^{-1}$ weaken as well with increasing $\mathrm{As}^{\mathrm{V}}$ contents (Figure $7 \mathrm{a}$ ). This observation can be explained by the fact that the specimen with the least $\mathrm{As}^{\mathrm{V}}$ content (i.e., FMA10G-02a) holds the maximum amorphous phases (Figure $4 \mathrm{a}$ ), which are more reactive than the crystalline phases in specimens with higher $\mathrm{As}^{\mathrm{V}}$ content (i.e., FMA10G-02b, and FMA10G-02c, see Figure 4a) to react with $\mathrm{CO}_{2}$ in the air to form the surface $\mathrm{CaCO}_{3}$. Given the above results, $\mathrm{As}^{\mathrm{V}}$ is likely to be immobilized in the geopolymer gels by physical encapsulation after curing for a short period (e.g., 2 - 7 days), $\underline{20}, \underline{22-}$ $\underline{23}$ and then to be incorporated into the crystalline minerals (e.g., calcium silicate and $\mathrm{CSH}$ ) during the phase transition processes as a result of prolonging the curing time.,$\frac{3}{19}$ 

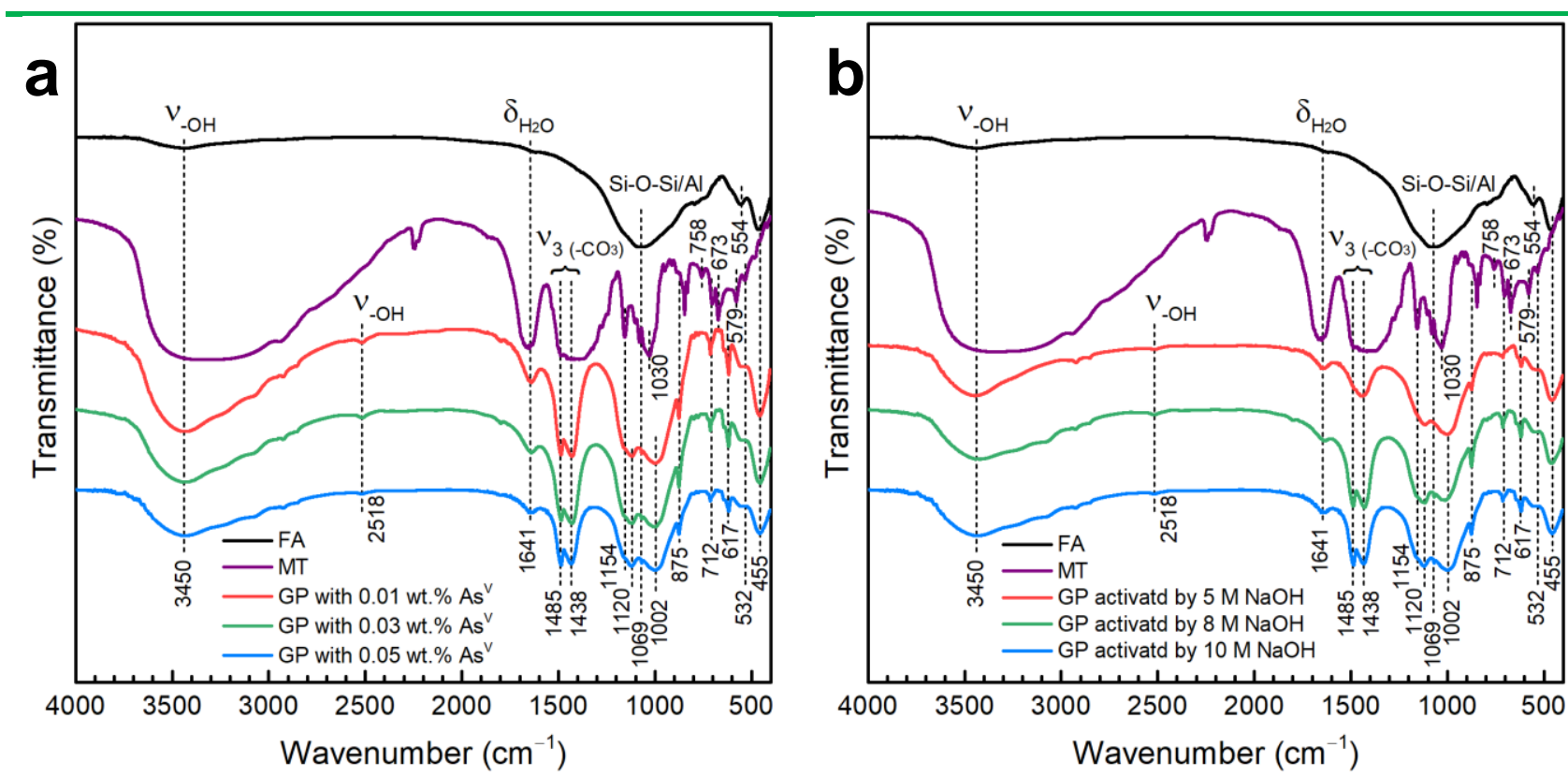

Figure 7 | FTIR spectra of the geopolymer specimens with 54 wt.\% FA curried for 7 days: (a) activated with $10 \mathrm{M} \mathrm{NaOH}$ and blended with varying $\mathrm{As}^{\mathrm{V}}$ contents, (b) blended with $0.05 \mathrm{wt} . \% \mathrm{As}^{\mathrm{V}}$ and activated with different concentrations of $\mathrm{NaOH}$. The spectra of both the FA and the MT are also presented for comparison.

Table 3 Assignment of characteristic vibrations to individual band in the geopolymer FTIR spectra.

\begin{tabular}{|c|c|c|}
\hline $\begin{array}{c}\text { Wavenumber } \\
\left(\mathrm{cm}^{-1}\right)\end{array}$ & Characteristic vibrations & Reference \\
\hline $3550-3225,3450$ & stretching $(-\mathrm{OH})$ & $\underline{25}, \underline{32}, \underline{50}$ \\
\hline 1798 & $\mathrm{v}_{1}+\mathrm{v}_{4}\left(-\mathrm{CO}_{3}\right)$ & $\underline{51}$ \\
\hline 1641 & bending $(\mathrm{H}-\mathrm{O}-\mathrm{H})$ & $\underline{3}, \underline{50}$ \\
\hline 1485 & asymmetric stretching $\left(\mathrm{v}_{3},-\mathrm{CO}_{3}\right)$ & $\underline{40}, \underline{51}$ \\
\hline 1438 & asymmetric stretching $\left(\mathrm{v}_{3},-\mathrm{CO}_{3}\right)$ & $\underline{3}, \underline{23}, \underline{51}$ \\
\hline $950-1200$ & stretching (Si-O-Si, Si-O-Al) & $\underline{31-32}, \underline{50}, \underline{52}$ \\
\hline 1154 & asymmetric stretching $(\mathrm{Si}-\mathrm{O}-\mathrm{Si})$ & $\underline{23}, \underline{31}$ \\
\hline 1120 & asymmetric stretching $(\mathrm{Si}-\mathrm{O}-\mathrm{Si}, \mathrm{Si}-\mathrm{O}-\mathrm{Al})$ & $\underline{52}$ \\
\hline 1069 & asymmetric stretching $(\mathrm{Si}-\mathrm{O}-\mathrm{Si}, \mathrm{Si}-\mathrm{O}-\mathrm{Al})$, symmetric stretching $\left(v_{1},-\mathrm{CO}_{3}\right)$ & $\underline{23}, \underline{51-52}$ \\
\hline 1030 & asymmetric stretching $(\mathrm{Si}-\mathrm{O}-\mathrm{Si}, \mathrm{Si}-\mathrm{O}-\mathrm{Al})$, symmetric stretching $\left(v_{1},-\mathrm{CO}_{3}\right)$ & $\underline{31}, \underline{40}, \underline{51}$ \\
\hline 1002 & symmetric stretching $\left(v_{1},-\mathrm{CO}_{3}\right), \mathrm{Si}-\mathrm{O}$ in $\mathrm{Q}^{2}$ sites & $\underline{40}, \underline{51}$ \\
\hline 875 & out-of-plane bending $\left(\mathrm{v}_{2},-\mathrm{CO}_{3}\right)$ & $\underline{12}, \underline{32}, \underline{51}$ \\
\hline 758 & bending $(\mathrm{Si}-\mathrm{O}-\mathrm{Si}, \mathrm{Si}-\mathrm{O}-\mathrm{Al})$ & $\underline{23}, \underline{40}$ \\
\hline 712 & in-plane bending $\left(v_{4},-\mathrm{CO}_{3}\right)$ & $\underline{3}, \underline{12}, \underline{51}$ \\
\hline 673 & bending $(\mathrm{Si}-\mathrm{O}-\mathrm{Si}$, in $\mathrm{CSH})$ & $\underline{39}, \underline{50}$ \\
\hline 617 & stretching $(\mathrm{Si}-\mathrm{O}-\mathrm{Si}, \mathrm{Si}-\mathrm{O}-\mathrm{Al})$ & $\underline{52}$ \\
\hline 579 & bending $(\mathrm{Si}-\mathrm{O}-\mathrm{Si}, \mathrm{Si}-\mathrm{O}-\mathrm{Al})$ & $\underline{23}$ \\
\hline 554 & bending $(\mathrm{Si}-\mathrm{O}-\mathrm{Al})$ & $\underline{23}, \underline{52}$ \\
\hline 532 & internal deformation of $\mathrm{SiO}_{4}$ & $\underline{23}, \underline{50}$ \\
\hline 455 & bending $(\mathrm{Si}-\mathrm{O}-\mathrm{Si})$ & $\underline{50}$ \\
\hline
\end{tabular}

\section{CONCLUSION}

Using fly ash, lead-zinc mine tailing, and FGD gypsum as the parent materials, a mixture of sodium hydroxide and sodium silicate solution as the alkali activator, geopolymer specimens were prepared and evaluated for their performance in both the compressive strength and the solidification/stabilization of arsenate from solid wastes in the current study. During the geopolymerization process, the increase in $\mathrm{NaOH}$ concentration accelerated the dissolution of aluminosilicate phases and thereby the formation of geopolymer, with increased alkalinity increasing the mechanical strength of the resultant geopolymer specimens. The compressive strength of geopolymer specimens increased with increasing fly ash content to a maximum of $54 \mathrm{wt} . \%$, beyond which the strength was reduced probably due to exceeding the optimum $\mathrm{Na} / \mathrm{Al}$ ratio at a very high fly ash content. The presence of arsenate appears to enhance the development of geopolymer strength when its content is at most 0.03 wt.\%, beyond which the 
strength was declined slightly owing to the same reason as mentioned above. However, all the specimens demonstrated excellent performance in the TCLP leaching tests for both arsenate and other heavy metal ions, with all complying with the Chinese leaching standard. Microstructural analyses suggest that arsenate is likely to be physically encapsulated along with the formation of geopolymer gels at first, and this physical-fixed $\mathrm{As}^{\mathrm{V}}$ may then be incorporated into the crystalline minerals (e.g., calcium silicate and $\mathrm{CSH}$ ) during phase transition processes. The fly ash/mine tailing-based geopolymers presented here can be potentially used as low-carbon $\mathrm{S} / \mathrm{S}$ materials for arsenic-contaminated soil remediation and as building materials given their superior mechanical strengths.

\section{ASSOCIATED CONTENT}

The Supporting Information is available free of charge on the ACS Publications website.

\section{AUTHOR INFORMATION}

\section{Corresponding Author}

Feihu Li - Collaborative Innovation Centre of Atmospheric Environment and Equipment Technology, Jiangsu Key Laboratory of Atmospheric Environment Monitoring and Pollution Control, School of Environmental Science and Engineering, Nanjing University of Information Science and Technology (NUIST), 219 Ningliu Road, Nanjing 210044, China; orcid.org/0000-00022969-8276; Email: fhli@nuist.edu.cn

\section{Authors}

Alseny Bah - Collaborative Innovation Centre of Atmospheric Environment and Equipment Technology, Jiangsu Key Laboratory of Atmospheric Environment Monitoring and Pollution Control, School of Environmental Science and Engineering, Nanjing University of Information Science and Technology (NUIST), 219 Ningliu Road, Nanjing 210044, China

Jie Jin - Collaborative Innovation Centre of Atmospheric Environment and Equipment Technology, Jiangsu Key Laboratory of Atmospheric Environment Monitoring and Pollution Control, School of Environmental Science and Engineering, Nanjing University of Information Science and Technology (NUIST), 219 Ningliu Road, Nanjing 210044, China

Andrea O. Ramos - Collaborative Innovation Centre of Atmospheric Environment and Equipment Technology, Jiangsu Key Laboratory of Atmospheric Environment Monitoring and Pollution Control, School of Environmental Science and Engineering, Nanjing University of Information Science and Technology (NUIST), 219 Ningliu Road, Nanjing 210044, China Author Contributions

F.L. designed and supervised the research; A.B., J.J., and A. R. performed the research; all authors analyzed the data; and F.L. and J.J. wrote the paper with inputs from all other authors.

Notes

The authors declare no competing financial interest.

\section{ACKNOWLEDGMENTS}

The work was partially supported by the National Natural Science Foundation of China (51002080, 51310105009).

\section{REFERENCES}

1. Podgorski, J.; Berg, M., Global threat of arsenic in groundwater. Science 2020, 368 (6493), 845-850.

2. Li, Y. C.; Min, X. B.; Chai, L. Y.; Shi, M. Q.; Tang, C. J.; Wang, Q. W.; Liang, Y. J.; Lei, J.; Liyang, W. J., Co- treatment of gypsum sludge and $\mathrm{Pb} / \mathrm{Zn}$ smelting slag for the solidification of sludge containing arsenic and heavy metals. J. Environ. Manage. 2016, 181, 756-761.

3. Li, Y. C.; Min, X. B.; Ke, Y.; Fei, J. C.; Liu, D. G.; Tang, C. J., Immobilization potential and immobilization mechanism of arsenic in cemented paste backfill. Miner. Eng. 2019, 138, 101-107.

4. Singh, R.; Singh, S.; Parihar, P.; Singh, V. P.; Prasad, S. M., Arsenic contamination, consequences and remediation techniques: A review. Ecotoxicol. Environ. Saf. 2015, 112, 247-270.

5. Nidheesh, P. V.; Singh, T. S. A., Arsenic removal by electrocoagulation process: Recent trends and removal mechanism. Chemosphere 2017, 181, 418-432.

6. Wang, C.; Luan, J.; Wu, C., Metal-organic frameworks for aquatic arsenic removal. Water Res. 2019, 158, 370-382.

7. Liu, B.; Kim, K. H.; Kumar, V.; Kim, S., A review of functional sorbents for adsorptive removal of arsenic ions in aqueous systems. J. Hazard. Mater. 2020, 388, 121815.

8. Alka, S.; Shahir, S.; Ibrahim, N.; Ndejiko, M. J.; Vo, D. V. N.; Abd Manan, F., Arsenic removal technologies and future trends: A mini review. J. Clean. Prod. 2021, 278, 123805.

9. Wang, L.; Cho, D. W.; Tsang, D. C. W.; Cao, X. D.; Hou, D. Y.; Shen, Z. T.; Alessi, D. S.; Ok, Y. S.; Poon, C. S., Green remediation of $\mathrm{As}$ and $\mathrm{Pb}$ contaminated soil using cementfree clay-based stabilization/solidification. Environ. Int. 2019, 126, 336-345.

10. Palansooriya, K. N.; Shaheen, S. M.; Chen, S. S.; Tsang, D. C. W.; Hashimoto, Y.; Hou, D. Y.; Bolan, N. S.; Rinklebe, J.; Ok, Y. S., Soil amendments for immobilization of potentially toxic elements in contaminated soils: A critical review. Environ. Int. 2020, 134, 105046.

11. Dutre, V.; Vandecasteele, C., Immobilization mechanism of arsenic in waste solidified using cement and lime. Environ. Sci. Technol. 1998, 32 (18), 2782-2787.

12. Jing, C. Y.; Korfiatis, G. P.; Meng, X. G., Immobilization mechanisms of arsenate in iron hydroxide sludge stabilized with cement. Environ. Sci. Technol. 2003, 37 (21), 5050-5056.

13. Singh, T. S.; Pant, K. K., Solidification/stabilization of arsenic containing solid wastes using portland cement, fly ash and polymeric materials. J. Hazard. Mater. 2006, 131 (1-3), 29-36.

14. Choi, W. H.; Lee, S. R.; Park, J. Y., Cement based solidification/stabilization of arsenic-contaminated mine tailings. Waste Manage. 2009, 29 (5), 1766-1771.

15. Wang, L.; Chen, L.; Guo, B. L.; Tsang, D. C. W.; Huang, L. B.; Ok, Y. S.; Mechtcherine, V., Red mud-enhanced magnesium phosphate cement for remediation of $\mathrm{Pb}$ and $\mathrm{As}$ contaminated soil. J. Hazard. Mater. 2020, 400, 123317.

16. Devi, P.; Kothari, P.; Dalai, A. K., Stabilization and solidification of arsenic and iron contaminated canola meal biochar using chemically modified phosphate binders. $J$. Hazard. Mater. 2020, 385, 121559.

17. Shi, C. J.; Qu, B.; Provis, J. L., Recent progress in low-carbon binders. Cem. Concr. Res. 2019, 122, 227-250.

18. Tian, Q. Z.; Chen, C. S.; Wang, M. M.; Guo, B. L.; Zhang, H. J.; Sasaki, K., Effect of Si/Al molar ratio on the immobilization of selenium and arsenic oxyanions in geopolymer. Environ. Pollut. 2021, 274, 116509.

19. Zhou, X.; Zhang, Z. F.; Yang, H.; Bao, C. J.; Wang, J. S.; Sun, Y. H.; Liu, D. W.; Shen, P. L.; Su, C., Red mud-metakaolin based cementitious material for remediation of arsenic pollution: Stabilization mechanism and leaching behavior of arsenic in lollingite. J. Environ. Manage. 2021, 300, 113715. 
20. Jiang, G. H.; Min, X. B.; Ke, Y.; Liang, Y. J.; Yan, X.; Xu, W. B.; Lin, Z., Solidification/stabilization of highly toxic arsenic-alkali residue by MSWI fly ash-based cementitious material containing Friedel's salt: Efficiency and mechanism. J. Hazard. Mater. 2022, 425, 127992.

21. Diaz-Loya, E. I.; Allouche, E. N.; Eklund, S.; Joshi, A. R.; Kupwade-Patil, K., Toxicity mitigation and solidification of municipal solid waste incinerator fly ash using alkaline activated coal ash. Waste Manage. 2012, 32 (8), 1521-1527.

22. Liu, D. G.; Ke, Y.; Min, X. B.; Liang, Y. J.; Wang, Z. B.; Li, Y. C.; Fei, J. C.; Yao, L. W.; Xu, H.; Jiang, G. H., Cotreatment of MSWI Fly Ash and Granulated Lead Smelting Slag Using a Geopolymer System. Int. J. Environ. Res. Public Health 2019, 16 (1), 156.

23. Opiso, E. M.; Tabelin, C. B.; Maestre, C. V.; Aseniero, J. P. J.; Park, I.; Villacorte-Tabelin, M., Synthesis and characterization of coal fly ash and palm oil fuel ash modified artisanal and small-scale gold mine (ASGM) tailings based geopolymer using sugar mill lime sludge as Ca-based activator. Heliyon 2021, 7 (4), e06654.

24. Kavitha, O. R.; Shanthi, V. M.; Arulraj, G. P.; Sivakumar, V. R., Microstructural studies on eco-friendly and durable Selfcompacting concrete blended with metakaolin. Appl. Clay Sci. 2016, 124, 143-149.

25. Ahmari, S.; Zhang, L. Y., Production of eco-friendly bricks from copper mine tailings through geopolymerization. Constr. Build. Mater. 2012, 29, 323-331.

26. Moukannaa, S.; Nazari, A.; Bagheri, A.; Loutou, M.; Sanjayan, J. G.; Hakkou, R., Alkaline fused phosphate mine tailings for geopolymer mortar synthesis: Thermal stability, mechanical and microstructural properties. J. Non-Cryst. Solids 2019, 511, 76-85.

27. Bah, A.; Feng, D. L.; Kedjanyi, E. A. K.; Shen, Z. Y.; Bah, A.; Li, F. H., Solidification of ( $\mathrm{Pb}-\mathrm{Zn})$ mine tailings by fly ash-based geopolymer I: influence of alkali reagents ratio and curing condition on compressive strength. J. Mater. Cycles Waste Manage. 2022, 24 (1), 351-363.

28. Izquierdo, M.; Querol, X.; Davidovits, J.; Antenucci, D.; Nugteren, H.; Fernandez-Pereira, C., Coal fly ash-slag-based geopolymers: Microstructure and metal leaching. J. Hazard. Mater. 2009, 166 (1), 561-566.

29. Giels, M.; Iacobescu, R. I.; Cappuyns, V.; Pontikes, Y.; Elsen, J., Understanding the leaching behavior of inorganic polymers made of iron rich slags. J. Clean. Prod. 2019, 238, 117736.

30. U.S. Environmental Protection Agency, Method 1311: Toxicity Characteristic Leaching Procedure. Washington, DC, 1992.

31. Rees, C. A.; Provis, J. L.; Lukey, G. C.; van Deventer, J. S. J., In situ ATR-FTIR study of the early stages of fly ash geopolymer gel formation. Langmuir 2007, 23 (17), 90769082.

32. Ahmari, S.; Ren, X.; Toufigh, V.; Zhang, L. Y., Production of geopolymeric binder from blended waste concrete powder and fly ash. Constr. Build. Mater. 2012, 35, 718-729.

33. van Jaarsveld, J. G. S.; van Deventer, J. S. J., Effect of the alkali metal activator on the properties of fly ash-based geopolymers. Ind. Eng. Chem. Res. 1999, 38 (10), 3932-3941.

34. Li, Q.; Xu, H.; Li, F. H.; Li, P. M.; Shen, L. F.; Zhai, J. P., Synthesis of geopolymer composites from blends of CFBC fly and bottom ashes. Fuel 2012, 97, 366-372.

35. Allahverdi, A.; Kani, E. N., Construction Wastes as Raw Materials for Geopolymer Binders. Int. J. Civ. Eng. 2009, 7 (3), 154-160.
36. Rowles, M.; O'Connor, B., Chemical optimisation of the compressive strength of aluminosilicate geopolymers synthesised by sodium silicate activation of metakaolinite. $J$. Mater. Chem. 2003, 13 (5), 1161-1165.

37. Shan, C. C.; Jing, Z. Z.; Pu, L.; Pan, X. H., Solidification of MSWI Ash at Low Temperature of 100 degrees C. Ind. Eng. Chem. Res. 2012, 51 (28), 9540-9545.

38. Zhang, D. N.; Yuan, Z. D.; Wang, S. F.; Jia, Y. F.; Demopoulos, G. P., Incorporation of arsenic into gypsum: Relevant to arsenic removal and immobilization process in hydrometallurgical industry. J. Hazard. Mater. 2015, 300, 272-280.

39. Zhang, Y. Y.; Zhang, S. Q.; Ni, W.; Yan, Q. H.; Gao, W.; Li, Y. Y., Immobilisation of high-arsenic-containing tailings by using metallurgical slag-cementing materials. Chemosphere 2019, 223, 117-123.

40. Tigue, A. A. S.; Malenab, R. A. J.; Dungca, J. R.; Yu, D. E. C.; Promentilla, M. A. B., Chemical Stability and Leaching Behavior of One-Part Geopolymer from Soil and Coal Fly Ash Mixtures. Minerals 2018, 8 (9), 411.

41. van Jaarsveld, J. G. S.; van Deventer, J. S. J.; Lukey, G. C., The effect of composition and temperature on the properties of fly ash- and kaolinite-based geopolymers. Chem. Eng. J. 2002, 89 (1-3), 63-73.

42. Zhang, L. Y.; Ahmari, S.; Zhang, J. H., Synthesis and characterization of fly ash modified mine tailings-based geopolymers. Constr. Build. Mater. 2011, 25 (9), 3773-3781.

43. Shadnia, R.; Zhang, L. Y., Experimental Study of Geopolymer Synthesized with Class F Fly Ash and LowCalcium Slag. J. Mater. Civ. Eng. 2017, 29 (10), 04017195.

44. Rovnanik, P., Effect of curing temperature on the development of hard structure of metakaolin-based geopolymer. Constr. Build. Mater. 2010, 24 (7), 1176-1183.

45. Akhter, H.; Cartledge, F. K.; Roy, A.; Tittlebaum, M. E., Solidification/stabilization of arsenic salts: Effects of long cure times. J. Hazard. Mater. 1997, 52 (2-3), 247-264.

46. Clancy, T. M.; Snyder, K. V.; Reddy, R.; Lanzirotti, A.; Amrose, S. E.; Raskin, L.; Hayes, K. F., Evaluating the cement stabilization of arsenic-bearing iron wastes from drinking water treatment. J. Hazard. Mater. 2015, 300, 522529.

47. PRC Ministry of Ecology and Environment, Identification Standards for Hazardous Wastes (GB 5085.3 - 2007). Beijing, China, 2007.

48. Bankowski, P.; Zou, L.; Hodges, R., Using inorganic polymer to reduce leach rates of metals from brown coal fly ash. Miner. Eng. 2004, 17 (2), 159-166.

49. Zhang, W.; Yao, X.; Yang, T.; Liu, C.; Zhang, Z. H., Increasing mechanical strength and acid resistance of geopolymers by incorporating different siliceous materials. Constr. Build. Mater. 2018, 175, 411-421.

50. Yu, P.; Kirkpatrick, R. J.; Poe, B.; McMillan, P. F.; Cong, X. D., Structure of calcium silicate hydrate (C-S-H): Near-, mid-, and far-infrared spectroscopy. J. Am. Ceram. Soc. 1999, 82 (3), 742-748.

51. Sow, P. Y. IR-Spectroscopic Investigations of the Kinetics of Calcium Carbonate Precipitation. University of Konstanz, Konstanz, Germany, 2016.

52. Lee, W. K. W.; van Deventer, J. S. J., Use of infrared spectroscopy to study geopolymerization of heterogeneous amorphous aluminosificates. Langmuir 2003, 19 (21), 87268734. 